Volume 5 Nomor 2

\title{
Hubungan Antara Penguasaan Kosakata dan Struktur Kalimat Bahasa Indonesia dengan Keterampilan Menulis Paragraf Argumentasi Siswa Kelas X SMA Negeri 6 Palopo
}

\author{
Yusni \\ STIKES Mega Buana Palopo \\ Yusnias09@gmail.com
}

\begin{abstract}
Abstrak
Penelitian ini bertujuan untuk mendeskripsikan: (1) Penguasaan kosakata siswa kelas X SMA Negeri 6 Palopo; (2) Penguasaan struktur kalimat bahasa Indonesia siswa kelas X SMA Negeri 6 Palopo; (3) Kemampuan menulis paragraf argumentasi siswa kelas X SMA Negeri 6 Palopo; (4) Hubungan yang signifikan penguasaan kosakata dan struktur kalimat bahasa Indonesia dengan keterampilan menulis paragraf argumentasi siswa kelas X SMA Negeri 6 Palopo. Penelitian ini merupakan penelitian korelasi ganda. Populasi penelitian ini adalah siswa kelas X SMA Negeri 6 Palopo tahun pelajaran 2015-2016 yang berjumlah 389 siswa. Sampel berjumlah 41 yang diambil menggunakan teknik purposive sampling. Instrumen pengumpulan data adalah penguasaan kosakata, penguasaan struktur kalimat, dan keterampilan menulis paragraf argumentasi. Analisis data yang digunakan Uji Persyaratan Analisis dan pengujian hipotesis melalui program SPSS 20 for window. Berdasarkan hasil penelitian yang ditemukan menunjukkan bahwa: hasil tes penguasaan kosakata nilai ratarata 81,254 . Terdapat 5 siswa atau $12.2 \%$ berada pada kategori sangat tinggi, sedangkan kategori sangat rendah hanya terdiri atas 3 siswa atau 7.3\%. Sisanya berada pada tingkat tinggi dan sedang sebanyak 33 siswa atau 80,5\%. Hasil tes penguasaan struktur kalimat menunjukkan bahwa nilai rata-rata 79,300. Terdapat 4 siswa atau 9,8\% berada pada kategori sangat tinggi, 16 siswa atau 39\% pada kategori tinggi diikuti 15 siswa atau 36.6\% pada tingkat sedang dan 6 siswa dengan kategori rendah sebesar 14,6\%. Hasil tes keterampilan menulis paragraf argumentasi menunjukkan bahwa nilai rata-rata 78,049. Terdapat 5 siswa atau $12.2 \%$ berada pada kategori sangat tinggi, sedangkan kategori sangat rendah hanya terdiri atas 6 siswa atau 14,6 \%. Sisanya berada pada tingkat tinggi dan sedang sebanyak 30 siswa atau 73,2\%. Hal ini menunjukkan bahwa variabel penguasaan kosakata dan struktur kalimat terhadap keterampilan menulis paragraf argumentasi adalah 48,5\%, sedangkan 51,5\% ditentukan oleh variabel lain yang tidak dijelaskan dalam kasus/pembahasan ini. Berdasarkan tabel model summary juga diperoleh nilai probabilitas (sig. $\mathrm{F}$ change) $=0,000$. Karena nilai sig. $\mathrm{F}$ change $0.000<0.05$ maka keputusannya adalah H0 ditolak dan $\mathrm{H} 1$ diterima. Hal ini berarti ada hubungan yang signifikan antara penguasaan kosakata dan struktur kalimat bahasa Indonesia dengan keterampilan menulis paragraf argumentasi siswa kelas X SMA Negeri 6 Palopo.
\end{abstract}

\section{Pendahuluan}

Kurikulum Tingkat Satuan Pendidikan (KTSP) yang didasarkan pada UU No. 20 Tahun 2003 tentang Sistem Pendidikan Nasional menyatakan bahwa Standar Nasional Pendidikan (SNP) terdiri atas standar isi, proses, kompetensi lulusan, tenaga kependidikan, sarana dan prasarana, pengelolaan, pembiayaan, dan penilaian pendidikan harus ditingkatkan secara berencana dan berkala Patombongi (2008:39); KTSP merupakan kurikulum operasional yang disusun dan dilaksanakan oleh masing-masing satuan pendidikan.

Pengembangan kurikulum pembelajaran bahasa Indonesia memiliki empat aspek keterampilan yang harus dikuasai, yaitu aspek keterampilan membaca, menyimak, berbicara, dan menulis. Keempat keterampilan tersebut sangat berhubungan antara satu dengan yang lainnya. Salah satu 
aspek keterampilan berbahasa yang akan dikembangkan penulis adalah keterampilan menulis.

Keterampilan menulis merupakan wujud keterampilan berbahasa yang sangat dibutuhkan, terutama dalam mengungkapkan ide, pikiran, dan perasaan melalui menulis fiksi maupun nonfiksi karena setiap penulis mempunyai pikiran atau gagasan yang ingin dituangkan dan disampaikan kepada pembaca. Bahkan, dalam kehidupan manusia, hampir tidak dapat dipisahkan dari kegiatan menulis. Oleh karena itu, keterampilan menulis harus diajarkan dengan baik kepada siswa karena terkadang ada siswa yang mampu berbicara dengan baik, namun tidak bisa menuliskan kembali apa yang telah dibicarakan. Sebaliknya, ada yang pandai menulis, tetapi tidak mampu menyampaikan isi tulisannya.

Menulis merupakan suatu keterampilan berbahasa yang dipergunakan untuk berkomunikasi secara tidak langsung (Nunan, 1991:86). Menulis adalah suatu kegiatan yang aktif dan produktif serta memerlukan cara berpikir yang teratur yang diungkapkan dalam bahasa tulis. Keterampilan seseorang untuk mengungkapkan ide, pikiran, gagasan, pengetahuan, ilmu, dan pengalaman sebagai suatu keterampilan yang produktif.

Keterampilan berbahasa yang sukar dikuasai oleh siswa adalah menulis. Kesulitan-kesulitan tersebut misalnya sukar menemukan ide atau bingung harus memulai tulisan. Walaupun sudah menemukan ide dan pendapat memulai tulisan, ada kalanya menghentikan tulisannya di tengah jalan. Hasilnya, tulisan akan menggantung dan tidak tuntas. Oleh karena itu, keterampilan menulis merupakan keterampilan berbahasa yang harus dilatih. Tanpa pelatihan berulang-ulang, kegiatan menulis tidak akan berhasil. Kegiatan menulis bukan kegiatan yang linear, melainkan kegiatan yang kreatif. Oleh sebab itu, siswa tidak menyelesaikan tulisannya pada saat itu juga, tetapi terus-menerus diperbaiki sehingga menjadi sempurna. Bahasa memiliki peranan yang sangat penting dalam kehidupan manusia, karena dengan bahasa manusia dapat berinteraksi dengan lingkungan sekitarnya. Melalui bahasa manusia dapat menyampaikan pesan baik lisan maupun tulisan kepada orang lain. Dengan bahasa pula dapat menentukan identitas penuturnya.

Kata menduduki posisi yang sangat penting dalam keterampilan berbahasa. Hal ini didukung oleh pendapat Keraf (2003:10) yang menyatakan bahwa, " Kualitas keterampilan berbahasa seseorang bergantung kepada kualitas dan kuantitas kosakata yang dimilikinya." Oleh sebab itu, keterampilan mengungkapkan dan menerima ide dengan baik sangat berhubungan dengan kosakata. Kata adalah media komunikasi. Berpikir dengan kata, berbicara dengan kata, mendengarkan kata dan menuliskan kata. Proses itu tidak dapat berlangsung dengan baik tanpa adanya penguasaan yang baik terhadap kosakata. Oleh karena itu, penguasaan kata dalam semua keterampilan berbahasa sangatlah penting. Penguasaan kosakata dalam satu bahasa berhubungan dengan jumlah kata yang harus dikuasai agar seseorang dapat menggunakan bahasa untuk berkomunikasi dan pemilihan kata serta pemakaiannya sesuai dengan 
konteks komunikasi. Setiap kata atau leksem memiliki makna. Pada awalnya, makna yang dimiliki sebuah kata adalah makna leksikal, makna denotatif, atau makna konseptual. Namun, dalam penggunaannya makna kata itu baru menjadi jelas kalau kata itu sudah berada di dalam konteks kalimatnya atau konteks situasinya.

Penguasaan kosakata merupakan hal yang sangat penting dalam menggunakan bahasa sebagai media komunikasi. Semakin banyak kosakata yang dimiliki maka semakin mudahlah menjalin komunikasi dengan pihak lain. Hal itu terjadi karena katalah yang menjadi hal utama dalam komunikasi.

Struktur kalimat dalam komunikasi merupakan seperangkat hubungan di antara kata-kata yang menghasilkan pernyataan, atau rumusan tertentu. Suatu struktur kalimat pada gilirannya akan mengatur posisi setiap kata di dalam kalimat. Jika suatu penyataan, misalnya, diformulasikan ke dalam struktur kalimat yang baik dan benar, dipastikan bahwa penulis akan dapat memahami dan mempersepsi pernyataan tersebut. Dengan demikian, dalam memahami suatu tulisan masalah struktur kalimat dan bagaimana menata serta mengelolahnya merupakan masalah penting dan mendasar. Meskipun struktur kalimat dalam suatu tulisan telah teratur secara baik dan benar, tidak berarti bahwa penulis dengan sendirinya dapat memahami dan mempersepsi informasi yang ada dalam struktur itu. Penulis juga harus menggunakan pengetahuan untuk mengolah dan memahami informasi (tulisan) yang ditulisnya. Dalam situasi yang demikian, dapat dipastikan bahwa tanpa penguasaan struktur kalimat yang memadai, seseorang tidak mungkin dapat mengerti dan memahami unit pesan yang terinformasi pada tiap kalimat yang dibaca.

Penguasaan dan pengenalan struktur kalimat yang memadai sebagaimana disebutkan di atas akan lebih baik lagi dalam menuliskan sebuah paragraf jika seseorang ditunjang dengan penguasaan kosakata, menentukan gagasan utama yang baik. Dengan mengetahui gagasan utama, penulis dapat memahami dengan sangat baik maksud dari tulisan.

Pembelajaran menulis di Sekolah Menengah Atas (SMA), unsur yang perlu diperhatikan setelah wacana adalah paragraf. Selain itu, pembelajaran menulis tidak terlepas dari latihan mengembangkan paragraf. Melalui keterampilan menulis paragraf, siswa akan mudah memahami dan menyampaikan gagasan, perasaan, kemauan, pengalaman, serta penghayatan terhadap lingkungan sekitarnya.

\section{Metode Penelitian}

Penelitian ini adalah penelitian kuantitatif korelasional. Metode penelitian yang digunakan dalam penelitian ini adalah metode survei melalui studi korelasional sebab melalui jenis penelitian korelasionaal ini bertujuan menyelidiki seberapa jauh variasi pada satu variabel berkaitan dengan variabel satu atau lebih variabel lain berdasarkan koefisien korelasi (Suwandi, 2006:6).

Melalui penelitian korelasional, pengukuran terhadap beberapa variabel tersebut dapat dilakukan serentak dalam kondisi realistik. Melalui 
studi korelasional peneliti dapat memperoleh informasi mengenai hubungan yang terjadi.

Terdapat tiga variabel dalam penelitian ini. Ketiga variabel tersebut adalah variabel-variabel bebasnya terdiri atas penguasaan kosakata $\left(\mathrm{X}_{1}\right)$ dan penguasaan struktur kalimat $\left(\mathrm{X}_{2}\right)$ sedangkan keterampilan menulis paragraf argumentasi (Y) sebagai variabel terikat. Sampel dalam penelitian ini adalah kelas X SMA Negeri 6 Palopo. sampel penelitian ini ditetapkan kelas X.5 berjumlah 41 orang yang menggunakan teknik purposive sampling. Hal ini didasarkan atas pertimbangan, kelas tersebut sebelumnya telah diajarkan materi struktur kalimat, paragraf argumentasi dan karakteristik sampel yang homogen. Teknik pengumpulan data dalam penelitian ini adalah sesuai dengan variabel penelitian ini, terdapat tiga jenis data yang dikumpulkan. Ketiga jenis data tersebut, yakni: (1) data hasil penguasaan kosakata (2), data hasil penguasaan struktur kalimat dan, (3) data hasil keterampilan menulis paragraf argumentasi. Sebelum tes diberikan secara menyeluruh terlebih dahulu diadakan uji coba instrumen. Uji coba instrumen dimaksudkan menguji tingkat validitas dan reliabilitas tes.

Teknik analisis data yang digunakan dalam penelitian ini adalah teknik analisis data kuantitatif yang digunakan untuk mengetahui korelasi atau hubungan penguasaan kosakata dan penguasaan struktur kalimat bahasa Indonesia dengan keterampilan menulis paragraf argumentasi yaitu: Sebelum menguji hipotesis untuk korelasi, terlebih dahulu dilakukan uji persyaratan analisis yang meliputi; (1) uji normalitas; (2) uji multikolinier; dan (3) uji heteroskedastisitas. Analisis deskripsi dilakukan terhadap seluruh ubahan beserta indikator-indikatornya, guna menggambarkan karakteristik setiap variabel penelitian meliputi: pembuatan daftar distribusi frekuensi, perhitungan rerata, simpangan baku, serta penentuan standar skor katagori setiap ubahan. Untuk mendeskripsikan data yang diperoleh dari hasil pengukuran dilakukan dengan cara mentabulasikan harga rerata, distribusi frekuensi dan histogram setiap ubahan, dengan menggunakan bantuan computer program SPSS 20 for window. Untuk menguji hipotesis dalam penelitian ini, maka digunakan korelasi gandaa dikarenakan terdapat dua variabel bebas dan satu variabel terikat yang mana variabel tersebut dihubungkan yaitu $\mathrm{X}_{1}$ dan $\mathrm{X}_{2}$ terhadap Y. Hipotesis tersebut diuji dengan menggunakan bantuan program SPSS 20 for window, dari hasil tersebut dapat diketahui F-hitung > F-tabel, atau nilai $p$-value pada kolom sig.< level of significant (a), dengan demikian dapat diketahui hasilnya apakah $p$-value pada kolom sig.< level of significant (a) atau lebih besar. Kalau sudah diketahui $p$-value pada kolom sig.< level of significant (a) dengan taraf korelasi $1 \%$ atau $5 \%$ maka variabel tersebut ada korelasi yang positif.

\section{Hasil Penelitian}

\section{Paparan Hasil Tes Penguasaan Kosakata Siswa}

Tes penguasaan kosakata dari 41 siswa digambarkan bahwa nilai rata-rata diperoleh siswa yaitu 81, nilai sangat tinggi yang diperoleh siswa yaitu 94 yang diperoleh tiga orang siswa, sedangkan nilai rendah 63 yang diperoleh satu orang siswa. hasil analisis data dengan 41 orang siswa yang 
dianalisis diperoleh gambaran, yaitu tidak ada siswa yang mampu memperoleh nilai 100 sebagai nilai maksimal. Terdapat 5 siswa atau $12.2 \%$ berada pada klasifikasi sangat tinggi, sedangkan kategori sangat rendah hanya terdiri atas 3 siswa atau 7.3\%. Sisanya berada pada tingkat tinggi dan sedang sebanyak 33 siswa atau 80,5\%. Disimpulkan bahwa penguasaan kosakata siswa berada pada tingkat kemampuan dengan kategori tinggi dengan 22 siswa atau 53.7\%. Hal ini terbukti dari penguasaan kosakata siswa yang menunjukkan bahwa siswa sepenuhnya memperhatikan kosakata dalam pembelajaran bahasa Indonesia. Siswa fokus untuk menyelesaikan soal tes pilihan ganda yang telah dibagikan dan memperhatikan petunjuk pengisian soal tes pilihan ganda. Hal itu telah membuktikan bahwa penguasaan kosakata berada pada kategori tinggi.

\section{Paparan Hasil Tes Penguasaan Struktur Kalimat Bahasa Indonesia Siswa}

Tes penguasaan struktur kalimat bahasa Indonesia dari 41 siswa digambarkan bahwa nilai rata-rata yang diperoleh siswa yaitu 79 , nilai sangat tinggi yang diperoleh siswa yaitu 94 yang diperoleh satu orang siswa, sedangkan nilai rendah 69 yang diperoleh enam orang siswa. Terdapat 4 siswa atau 9,8 \% berada pada kategori sangat tinggi, 16 siswa atau 39\% pada tingkat klasifikasi tinggi diikuti 15 siswa atau $36.6 \%$ pada tingkat sedang dan 6 siswa dengan klasifikasi rendah sebesar 14,6\%. Disimpulkan bahwa penguasaan struktur kalimat siswa berada pada tingkat kemampuan dengan kategori tinggi dengan 16 siswa atau 39\%. Hal ini terbukti dari penguasaan struktur kalimat bahasa Indonesia siswa yang menunjukkan bahwa siswa sepenuhnya memperhatikan struktur kalimat bahasa Indonesia dalam pembelajaran bahasa Indonesia. Siswa fokus untuk menyelesaikan soal tes pilihan ganda yang telah dibagikan dan memperhatikan petunjuk pengisian soal tes pilihan ganda. Hal itu telah membuktikan bahwa penguasaan struktur kalimat bahasa Indonesia berada pada kategori tinggi.

\section{Paparan Hasil Tes Keterampilan Menulis Paragraf Argumentasi Siswa}

Tes keterampilan menulis paragraf argumentasi dari 41 siswa digambarkan bahwa nilai rata-rata yang diperoleh siswa yaitu 78 , nilai sangat tinggi yang diperoleh siswa yaitu 95 yang diperoleh satu orang siswa, nilai 90 diperoleh empat orang siswa sedangkan nilai rendah 65 yang diperoleh enam orang siswa. Terdapat 5 siswa atau $12.2 \%$ berada pada klasifikasi sangat tinggi, sedangkan kategori sangat rendah hanya terdiri atas 6 siswa atau 14,6\%. Sisanya berada pada tingkat tinggi dan sedang sebanyak 30 siswa atau 73,2\%. Disimpulkan bahwa keterampilan menulis paragraf argumentasi siswa berada pada tingkat kemampuan dengan kategori tinggi dengan 17 siswa atau 41,5\%. Hal ini terbukti dari hasil keterampilan menulis paragraf argumentasi siswa yang menunjukkan bahwa siswa sepenuhnya memperhatikan langkah-langkah penulisan paragraf argumentasi yaitu (1) menentukan topik, (2) menemukan judul, (3) menyusun kerangka, (4) mengumpulkan bahan atau data, dan (5) mengembangkan kerangka. Siswa fokus menuliskan paragraf dengan tema yang telah mereka tentukan dan menulisnya dalam bentuk paragraf argumentasi. Hal itu telah membuktikan 
bahwa keterampilan menulis paragraf argumentasi siswa berada pada kategori tinggi.

\section{Pembahasan}

Pembahasan hasil penelitian ini dipaparkan interpretasi tes hasil penelitian berdasarkan data yang diperoleh yang mempresentasikan penguasaan kosakata, struktur kalimat bahasa Indonesia dan keterampilan menulis paragraf argumentasi siswa kelas X.5 SMA Negeri 6 Palopo.

\section{Hasil Penilaian Penguasaan Kosakata Siswa}

Hasil analisis data dengan 41 orang siswa yang dianalisis diperoleh gambaran, yaitu tidak ada siswa yang mampu memperoleh nilai 95 samapi nilai 100 sebagai nilai maksimal. Penilaian secara umum hasil tes pilihan ganda penguasaan kosakata siswa kelas X.5 SMA Negeri 6 Palopo meliputi lima kategori yaitu, sangat tinggi, tinggi, sedang, rendah dan sangat rendah. Dari hasil tersebut diketahui bahwa penguasaan kosakata siswa kelas X.5 SMA Negeri 6 Palopo berada pada kategori tinggi karena dari 41 siswa yang dianalisis siswa menjawab soal pilihan ganda dengan benar hanya 33 siswa. Dari segi penggunaan imbuhan-an yang artinya menyatakan alat siswa keliru memilih penggunaan imbuhan-an yaitu pinggiran, yang seharusnya penggunaan imbuhan-an yang menyatakan alat adalah jalanan. Pada penulisan ke- yang kurang tepat siswa keliru memilih penulisan ke- yang kurang tepat yaitu keluarkanlah, yang seharusnya penggunaan ke- yang kurang tepat adalah keluarbiasaan. Pada penggunaan kata bilangan tingkat siswa keliru memilih penggunaan kata bilangan bertingkat yaitu tiga anak itu, yang seharusnya penggunaan kata bilangan bertingkat adalah kelima buku. Pada bentuk kata yang baku siswa keliru memilih yaitu standardisasi, yang seharusnya bentuk kata yang baku adalah standarisasi. Pada penggunaan kata penghubung siswa keliru memilih kata penghubung yang tepat yaitu baik laki-laki dan perempuan, yang seharusnya kata penghubung yang benar adalah baik laki-laki maupun perempuan.

Berdasarkan temuan ini, penguasaan kosakata tidak terlepas dari kegiatan memahami komponen bahasa yang memuat daftar kata-kata beserta batasannya yang penggunaannya sesuai dengan makna dan fungsinya. Kemampuan berbahasa seseorang sangat bergantung kepada kuantitas dan kualitas kosakata yang dimiliki. Semakin kaya kosakata yang dimiliki seseorang, semakin memungkinkan mereka terampil berbahasa. Penguasaan kosakata dapat diartikan sebagai kemampuan seseorang mempergunakan kata-kata dalam berkomunikasi lisan maupun tulisan. Hal ini sesuai dengan (Nurgiyantoro, 2001:213) menyatakan bahwa penguasaan kosakata adalah kemampuan untuk mempergunakan kata-kata. Kemampuan untuk memahami diwujudkan dalam kegiatan membaca dan menyimak, sedangkan kemampuan mempergunakan diwujudkan dalam kegiatan menulis dan berbicara.

Dapat dipahami bahwa kualitas dan kuantitas kosakata atau pembendaharaan kata yang dimiliki siswa akan membantu siswa tersebut dalam menyerap berbagai informasi yang disampaikan para pengajar atau informasi dari berbagai sumber belajar lainnya. Penguasaan kosakata yang 
baik sangat mempengaruhi kemampuan siswa dalam berkomunikasi, baik lisan maupun tulisan. Pentingnya pembelajaran kosakata terhadap peningkatan dan pengembangan kemampuan siswa berbahasa menyebabkan pembelajaran bahasa sebaiknya dilakukan secara lebih serius dan terarah. Hal ini dikarenakan di lapangan masih banyak dijumpai siswa-siswa yang mengalami kesulitan dalam melakukan pembelajaran bahasa Indonesia terutama tampak pada saat pembelajaran empat keterampilan berbahasa (menyimak, berbicara, membaca dan menulis) yang disebabkan kemampuan penguasaan kosakata Indonesia siswa perlu ditingkatkan.

\section{Hasil Penilaian Penguasaan Struktur Kalimat Bahasa Indonesia Siswa}

Penilaian secara umum hasil tes pilihan ganda penguasaan struktur kalimat bahasa Indonesia siswa kelas X.5 SMA Negeri 6 Palopo meliputi lima kategori yaitu, sangat tinggi, tinggi, sedang, rendah dan sangat rendah. Hasil tersebut diketahui bahwa penguasaan struktur kalimat bahasa Indonesia siswa kelas X.5 SMA Negeri 6 Palopo secara umum tergolong tinggi.

Selain dilakukan penilaian secara umum, penilaian penguasaan struktur kalimat bahasa Indonesia juga dilakukan per indikator. Pertama, kalimat tunggal yang terdapat pada butir soal, 4, 5, 6, 8, 10, 14, 17, 22, 23, 28, 34 dan 35, berada pada kategori tinggi karena siswa yang menjawab kurang tepat yaitu pada penggunaan predikat anak malas itu datang terlambat siswa keliru memilih penggunaan predikat yaitu malas yang seharusnya penggunaan predikat anak malas itu datang terlambat adalah datang terlambat. Pada kategori kalimat lengkap siswa keliru memilih yaitu telah sampai di Bali, yang seharusnya kategori kalimat lengkap adalah Adik mengerjakan tugas ilmiha. Pada penggunaan unsur keterangan siswa keliru memilih penggunaan unsur keterangan yaitu tujuan, yang seharusnya penggunaan unsur keterangan adalaha cara. Kedua, penilaian kalimat majemuk sederhana yang terdapat pada butir soal, 9, 11, 12, 16, 18, 19, 20 , 24, 25, 31 dan 32. Dari hasil nalisis data diketahui siswa menjawab indikator kalimat majemuk pada kategori kalimat lengkap siswa keliru memilih yaitu telah sampai ke Bali, yang seharunya kategori kalimat lengkap adalah Adik mengerjakan tugas ilmiah. Ketiga, penilaian indikator kalimat majemuk bertingkat yang terdapat pada butir soal 15 dan 27. Dari hasil analisis data diketahui siswa menjawab indikator majemuk bertingkat yang tergolong kalimat efektif siswa keliru memilih yaitu para anak remaja itu saling pukul dengan menggunakan tangan kosong, seharusnya yang tergolong kalimat efektif adalah Dono menolong dan membantu anak kecil yang tersesat di pasar. Keempat, penilaian indikator majemuk setara, yang terdapat pada butir soal, 13,26, dan 29. Dari hasil analisi data diketahui siswa memilih indikator kalimat majemuk setara yang menggunakan keterangan setara yaitu buku itu bermanfaat untuk dibaca, seharusnya yang tergolong kalimat mejemuk setara yang menggunakan keterangan adalah Anita pergi ke Surabaya bersama Ibunya. Kelima, penilaian penguasaan struktur kalimat bahasa Indonesia, indikator pola kalimat, yang terdapat pada butir soal 1, 2, $3,7,21,30$ dan 33. Dari hasil analisis data diketahui indikator pola kalimat yaitu siswa memilih rumah kuno itu ada hantunya sebagai kalimat yang 
berpola K-S-P-0, yang seharusnya kalimat yang berpola K-S-P-O adalah di toko itu beliau membeli buku.

Indikator pola kalimat, soal pilihan ganda yang diberikan merupakan kalimat yang berpola subjek, predikat, objek dan keterangan. Kalimat yang di gunakan sesungguhnya dapat dikembalikan ke dalam sejumlah kalimat dasar yang sangat terbatas. Dengan perkataan lain, semua kalimat yang di gunakan berasal dari beberapa pola kalimat dasar saja. Sesuai dengan kebutuhan masing-masing, kalimat dasar tersebut di kembangkan, yang pengembangannya itu tentu saja harus didasarkan pada kaidah yang berlaku. Pola kalimat subjek-predikat, subjek-predikat-objek, subjek-predikat-objekketerangan yang banyak ditemukan dalam buku acuan kelas X sehingga siswa lebih memahami pola kalimat tersebut sehingga lebih mudah dalam menjawab soalnya. Meskipun demikian beberapa siswa masih kesulitan dalam memahami pola kalimat keseluruhan karena hanya dapat menentukan pola kalimat beberapa soal saja. Dari dua sub penilaian dengan lima indikator yang dinilai penguasaan struktur kalimat bahasa Indonesia yang digunakan pada tes pilihan ganda, penguasaan struktur kalimat bahasa Indonesia paling rendah terdapat pada indikator kalimat majemuk setara.

Pengetahuan dan pengenalan struktur kalimat yang memadai akan membuat pemahaman mengenai tulisan akan lebih meningkat. Stuktur kalimat pada dasarnya akan mengatur posisi setiap kata didalam kalimat. Jika suatu pernyataan, diformulasikan ke dalam struktur kalimat yang baik dan benar, dipastikan bahwa siswa dapat memahami dan mempersepsi pernyataan tersebut. Hal ini sesuai dengan pendapat Ramlan (1996:46) menyatakan bahwa kegramatikalan kalimat akan sangat menentukan apakah suatu penuturan dapat diterima karena bermakna, atau sebaliknya ditolak karena tidak bermakna atau tidak secara cermat menyampaikan maksud tertentu". Dengan demikian, memahami suatu tulisan masalah struktur kalimat dan bagaimana menata kalimat sehingga terbentuk suatu paragraf yang baik. Meskipun struktur kalimat dalam suatu tulisan telah teratur secara baik dan benar, tidak berarti siswa dengan sendirinya dapat memahami dan mempersepsi informasi yang ada dalam struktur kalimat. Siwa juga harus menggunakan penguasaan kosakata yang memadai untuk mengolah dan memahami informasi (tertulis) yang akan ditulis. Situasi demikian, dapat dipastikan tanpa pengetahuan struktur kalimat yang memadai, siswa tidak mungkin dapat mengerti dan memahai unit pesan yang akan ditulis dalam sebuah paragraf.

Secara empirik menunjukkan bahwa penguasaan struktur kalimat bahasa Indonesia siswa merupakan salah satu faktor penentu bagi tinggi rendahnya keterampilan menulis paragraf argumentasi. Temuan ini mengisyaratkan bahwa upaya penguasaan struktur kalimat harus dikaji dari pemahaman struktur kalimat yang terdiri atas: (1) bentuk kalimat, dan (2) pola kalimat. Bentuk kalimat terdiri atas kalimat tunggal dan kalimat majemuk. Aspek kalimat tunggal dan aspek kalimat mejemuk.

Penguasaan stuktur kalimat dapat saling dipertukarkan dengan mengacu pada penguasaan konsep struktur kalimat. Setiap bahasa adalah unit dalam kosakata dan kalimat-kalimat yang disusun dapat dipahami 
dengan mudah. Tata bahasa mengacu pada analisis bahasa secara deskriptif yang mencoba menjelaskan prinsip-prinsip struktur bahasa dan susunan kata-kata. Lewat struktur bahasa seseoang dapat memahami (reseptif) dan menyampaikan (produktif), makna tulisan karena struktur bahasa sangat diperlukan. Struktur bahasa menunjukkan aturan-aturan atau kaidah bahasa.

Kalimat majemuk setara ini tidak memiliki anak kalimat. Hal ini sesuai dengan pendapat Dola (2011:86) bahwa "pada dasarnya kalimat majemuk sering pula disebut kalimat setera, karena klausa-kaluasa yang membentukya memilikistatus yang sama, setera, atau sederajat. Klausaklausa yang setera dalam kalimat majemuk dihubungkan dengan konjungsi koordinatif, seperti dan, atau, tetapi, lalu. Akan tetapi tak jarang hubungan itu hanya secara implisit, tanpa menggunakan konjungsi".

\section{Hasil Penilaian Menulis Paragraf Argumentasi Siswa}

Pembelajaran menulis khususnya menulis paragraf argumentasi bertujuan agar siswa terampil dalam menuliskan gagasan, ide, pikiran, dan pendapatnya disertai dengan fakta-fakta sebagai bukti pendukung sehingga gagasan atau pendapatnya dapat diterima serta memengaruhi pembaca. Untuk terampil menulis paragraf argumentasi, sebaiknya siswa memahami terlebih dahulu hakikat sebuah paragraf argumentasi itu sendiri, sehingga siswa dapat menulis paragraf argumentasi yang sesuai dengan kriteria penulisan paragraf argumentasi.

Hasil penelitian menunjukkan aspek penilaian paragraf argumentasi beradasarkan indikator kesesuaian isi dengan ciri-ciri, siswa mengemukakan pendapat sesuai dengan topik, memaparkan fakta yang mendukung memperoleh nilai rata-rata 2,68 dari 41 siswa. Aspek penilaian paragraf argumentasi beradasarkan indikator kesesuaian isi dengan topik, paragraf yang dibuat siswa menarik untuk dibaca dan memaparkan topik yang diajukan dengan memperoleh nilai rata-rata 2,66 dari 41 siswa. Aspek penilaian paragraf argumentasi beradasarkan indikator organisasi isi, gagasan diungkapkan dengan jelas, tertata dengan baik, urutan logis, dengan memperoleh nilai rata-rata 2,52 dari 41 siswa. Aspek penilaian paragraf argumentasi beradasarkan indikator ejaan dan tata tulis, jumlah kesalahan kurang dari lima, memperoleh nilai rata-rata 2,58 dari 41 siswa. Aspek penilaian paragraf argumentasi beradasarkan indikator ketepatan diksi dengan memperoleh nilai rata-rata 2,36 dari 41 siswa.

Hasil menulis paragraf argumentasi dapat dilihat dari hasil menulis paragraf argumentasi siswa kode sampel 008 sebagai berikut.

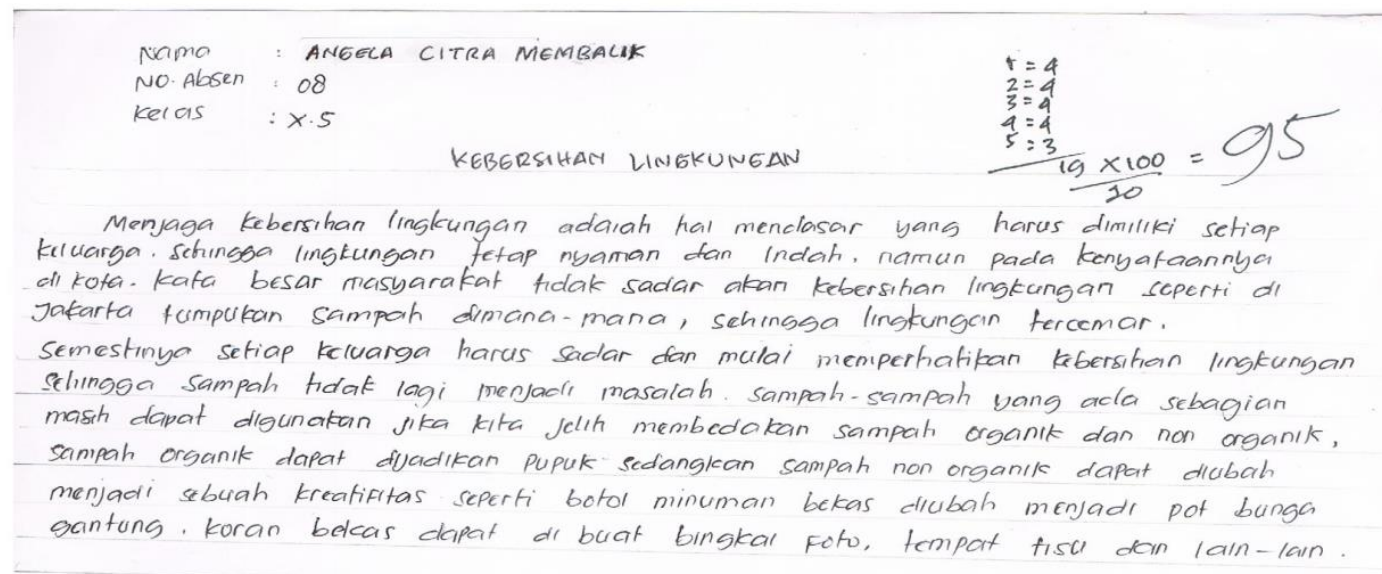




\section{Tinggi}

Gambar 4.1 Hasil Menulis Paragraf Argumentasi Siswa Nilai Sangat

Hasil menulis siswa yang tampak pada gambar 4.4 merupakan perolehan nilai sangat tinggi. Dalam menulis paragraf argumentasi terdiri atas lima aspek yang harus diperhatikan siswa yaitu kesesuaian isi dengan ciri-ciri argumentasi, kesesuaian isi dengan topik, organisasi isi, ejaan dan tata tulis dan ketepatan diksi. Perolehan nilai menulis paragraf argumentasi pada gambar 4.1 yaitu aspek kesesuaian isi dengan ciri-ciri argumentasi siswa mengemukakan pendapat sesuai dengan topik yang dipilih yaitu kebersihan lingkungan memaparkan fakta yang mendukung yaitu tumpukan sampah dimana-mana, ada simpulan yaitu sampah non organik dapat diubah menjadi sebuah kreatifitas seperti botol minuman bekas diubah menjadi pot bunga gantung, koran bekas dapat dibuat bingkai foto sehingga memperoleh nilai 4. Pada aspek kesesuaian isi dengan topik, paragraf yang dibuat menarik untuk dibaca karena topik yang dibuat adalah kebersihan lingkungan disertai fakta yang ada, dan memaparkan topik yang diajukan sehingga memperoleh nilai 4. Pada aspek organisasi isi, gagasan diungkapkan dengan jelas yaitu setiap keluarga harus sadar dan mulai memperhatikan kebersihan lingkungan sehingga sampah tidak lagi menjadi masalah, tertata dengan baik yaitu dari topik kebersihan lingkungan sampai pada kesimpulan dan urutan logis, sehingga memperoleh nilai 4. Pada aspek ejaan dan tata tulis, jumlah kesalahan kurang dari lima seperti penggunaan tanda titik, (...setiap keluarga. sehingga...), tanda koma (... indah, namun...), dan penulisan huruf kapital (... tumpukan Sampah...) sehingga memperoleh nilai 4. Sedangkan pada aspek ketepatan diksi, pilihan kata dan ungkapan tepat yaitu ornaik dan non organik, kurang menguasai pembentukan kata sehingga memperoleh nilai 3.

Hasil menulis paragraf argumentasi siswa kode sampel 020 sebagai berikut.

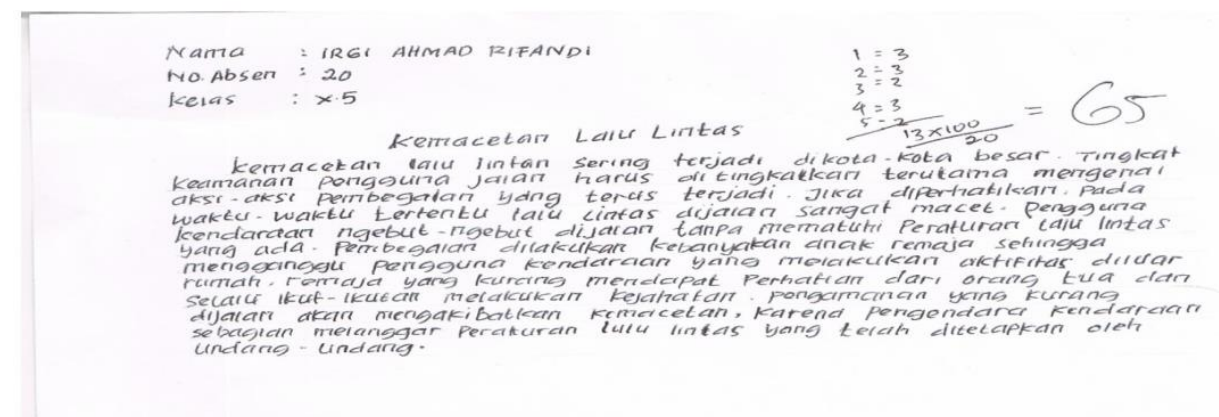

Gambar 4.1 Hasil Menulis Paragraf Argumentasi Siswa Nilai Rendah

Hasil menulis siswa yang tampak pada gambar 4.1 merupakan perolehan nilai rendah. Dalam menulis paragraf argumentasi terdiri atas lima aspek yang harus diperhatikan siswa yaitu kesesuaian isi dengan ciri-ciri argumentasi, kesesuaian isi dengan topik, organisasi isi, ejaan dan tata tulis dan ketepatan diksi. Perolehan nilai menulis paragraf argumentasi pada gambar 4.1 yaitu aspek kesesuaian isi dengan ciri-ciri argumentasi, siswa mengemukakan pendapat sesuai dengan topik yaitu kemacetan lalu lintas, memaparkan fakta yang mendukung seperti di kota-kota besar, tidak ada simpulan sehingga memperoleh nilai 3. Pada aspek kesesuaian isi dengan 
topik, paragraf yang dibuat menarik untuk dibaca yaitu kemacetan lalu lintas di kota-kota besar tetapi kurang mampu memaparkan topik yang diajukan sehingga memperoleh nilai 3. Pada aspek organisasi isi, gagasan diungkapkan dengan jelas, kurang tertata dengan baik karena gagasan yang diungkapkan menceritakan secara berulang, sehingga urutan tidak logis, sehingga memperoleh nilai 2. Pada aspek ejaan dan tata tulis, jumlah kesalahan antara lima sampai dengan sepuluh seperti penggunaan huruf kapital dan huruf kecil ... lintan ... Pembegalan ... undang-undang ... Pengguna ... Peraturan ... sehingga memperoleh nilai 3. Sedangkan pada aspek ketepatan diksi, pilihan kata dan ungkapan tidak tepat seperti pengamanan, kurang menguasai pembentukan kata yaitu sehingga memperoleh nilai 2 .

Keterampilan menulis tidak terbentuk secara otomatis, seseorang yang ingin terampil menulis memerlukan pembelajaran serta latihan yang teratur. Hal ini sesuai dengan (Wiyanto, 2004:7) menyatakan proses penguasaan keterampilan menulis sama halnya dengan penguasaan berbicara. Bedanya keterampilan berbicara perlu mendengarkan terlebih dahulu sedangkan menulis terlebih dahulu banyak membaca. Semakin banyak membaca dan semakin sering menirukan bacaan dalam tulisan, maka penguasaan dan keterampilan menulis cepat dikuasai. Namun, tidaklah berlebihan jika dikatakan bahwa kemampuan menulis merupakan kemampuan yang kompleks yang menuntut sejumlah pengetahuan dan keterampilan yang sistematis. Oleh sebab itu, untuk menguasai keterampilan menulis seharusnya dipelajari secara formal dan dilakukan secara bertahap, yakni prapenulisan, tahap penulisan, dan tahap revisis.

Adanya harapan-harapan tersebut mendorong penulis untuk melihat langsung kenyataan yang ada di sekolah dan untuk mengetahui bagaimana tingkat keterampilan siswa dalam menulis paragraf argumentasi. Kenyataan di lapangan menunjukkan bahwa keterampilan siswa dalam menulis paragraf, terutama paragraf argumentasi masih banyak hal yang perlu ditingkatkan. Kesimpulan dari penelitian ini keterampilan menulis paragraf argumentasi siswa kelas X.5 dikatagorikan tinggi dengan nilai rata-rata yang diperoleh seluruh siswa kelas X.5, 81,254. Jadi jawaban hipotesis diterima.

\section{Hubungan antara Penguasaan Kosakata dan Struktur Kalimat dengan Menulis Paragraf Argumentasi Siswa}

Berdasarkan hasil penelitian yang telah dipaparkan penguasaan kosakata siswa berada pada tingkat kemampuan dengan kategori tinggi. Penguasaan struktur kalimat siswa berada pada tingkat kemampuan dengan kategori tinggi. Keterampilan menulis paragraf argumentasi siswa berada pada tingkat kemampuan dengan kategori tinggi.

Diketahui bahwa besarnya hubungan antara penguasaan kosakata dan struktur kalimat (secara simultan) terhadap keterampilan menulis paragraf argumentasi yang dihitung dengan koefesien korelasi adalah 0.498, hal ini menunjukkan hubungan yang cukup. Selain itu, koefisien korelasi 0,498 lebih besar dari $r$-table (dengan $\mathrm{df}=\mathrm{n}-2$ atau $41-2=39$,) dimana 0.498 $>0.316$. Selain itu, kontribusi atau sumbangan secara simultan variabel penguasaan kosakata dan struktur kalimat terhadap keterampilan menulis 
paragraf argumentasi adalah 48,5\%, sedangkan 51,5\% ditentukan oleh variabel lain yang tidak dijelaskan dalam kasus/pembahasan ini. Berdasarkan tabel model summary juga diperoleh nilai probabilitas (sig. F change) $=0,000$. Karena nilai sig. F change $0.000<0.05$ maka keputusannya adalah $\mathrm{H}_{0}$ ditolak dan $\mathrm{H}_{1}$ diterima. Hal ini berarti ada hubungan yang signifikan antara penguasaan kosakata dan struktur kalimat bahasa Indonesia dengan keterampilan menulis paragraf argumentasi siswa kelas X.5 SMA Negeri 6 Palopo.

Hasil penelitian ini tidak sama dengan hasil penelitian yang dilakukan oleh peneliti terdahulu. Hasil penelitian yang dilakukan oleh Sasmayunita (2014) dengan judul " Hubungan antara Penguasaan Gagasan Utama dan Struktur Kalimat dengan Hasil Belajar Membaca Pemahaman pada Siswa Kelas VIII SMP Negeri 1 Soppeng Riaja Barru. Menunjukkan penguasaan gagasan utama memberi kontribusi 60,7\% kepada kemampuan membaca pemahaman dan penguasaan struktur kalimat dengan kemampuan membaca pemahaman terdapat hubungan yang positif antara kedua variabel dengan nilai signifikan 5\%,. Berdasarkan temuannya peningkatan penguasaan struktur sangat diperlukan sebagai upaya meningkatkan kemampuan membaca pemahaman.

Selain itu, penelitian yang dilakukan oleh Darsan Bagus (2015) dengan judul "Korelasi Penguasaan Kalimat dengan Kemampuan Menulis Argumentasi Mahasiswa PGSD, Fakultas Keguruan dan Ilmu Pendidikan, Universitas Palangka Raya". Hasil penelitian yang dilakukan di Universitas Palangkaraya mengungkapkan bahwa penguasaan kalimat sangat besar sekali yaitu 93,5\% yang menunjukkan bahwa variabel penguasaan kalimat memberikan korelasi terhadap variabel kemampuan menulis argumentasi, dan sisanya sebesar 6,5\% merupakan kontribusi dari variabel lain yang tidak diteliti atau dapat disebut variabel intervining.

Meskipun penelitian sebelumnya hampir sama, tetapi fokus penelitiannya berbeda. Penelitian yang dilakukan oleh Sasmayunita, fokus penelitiannya mengulas mengenai penguasaan gagasan utama dan struktur kalimat dengan hasil belajar membaca pemahaman. Penelitian yang dilakukan oleh Darsan Bagus fokus penelitiannya korelasi penguasaan kalimat dengan kemampuan menulis argumentasi. Sementara untuk penelitian ini fokus pada penguasaan kosakata dan struktur kalimat bahasa Indonesia dengan keterampilan menulis paragraf argumentasi siswa kelas $\mathrm{X}$ SMA Negeri 6 Palopo.

\section{Simpulan}

Pertama, hasil penguasaan kosakata dikategorikan tinggi dengan tingkat persentase penguasaan mencapai 22 siswa $(53,7 \%)$ yang mendapat nilai 80 sampai nilai 94, tidak ada siswa yang mencapai nilai 95 sampai nilai 100.

Kedua, hasil penguasaan struktur kalimat dikategorikan tinggi dengan tingkat persentase penguasaan mencapai 16 siswa $(53,7 \%)$ yang mendapat nilai 80 sampai 94, tidak ada siswa yang mencapai nilai 95 sampai nilai 100. 
Ketiga, hasil keterampilan menulis paragraf argumentasi dikategorikan tinggi dengan tingkat persentase keterampilan mencapai 17 siswa $(41,5 \%)$ yang mendapat nilai 80 sampai 95 , tidak ada siswa yang mencapai nilai 96 sampai nilai 100.

Diketahui besarnya hubungan antara penguasaan kosakata dan struktur kalimat bahasa indonesia (secara simultan) terhadap keterampilan menulis paragraf argumentasi yang dihitung dengan koefesien korelasi adalah 0.498 , hal ini menunjukkan hubungan yang cukup.

Koefisien korelasi 0,498 lebih besar dari r-tabel (dengan $\mathrm{df}=\mathrm{n}-2$ atau 41-2 = 39,) dimana $0.498>0.316$. Berdasarkan tabel model summary juga diperoleh nilai probabilitas (sig. $\mathrm{F}$ change) $=0,000$. Karena nilai sig. $\mathrm{F}$ change $0.000<0.05$ maka keputusannya adalah $\mathrm{H}_{0}$ ditolak dan $\mathrm{H}_{1}$ diterima. Hal ini berarti ada hubungan yang signifikan antara penguasaan kosakatdan struktur kalimat bahasa Indonesia dengan keterampilan menul. paragraf argumentasi siswa.

\section{Daftar Pustaka}

Adisumarta, Mukidi. 1984. Pengantar Ilmu Bahasa Umum. Yogyakarta: IKIP FPBS.

Akhadiah, Sabarti dkk.1988. Pembinaan Kemampuan Menulis Bahasa Indonesia. Jakarta: Erlangga.

Akhadiah, Sabarti. dkk. 1995. Pembinaan Menulis Bahasa Indonesia. Jakarta: Erlangga.

Akhadiah, Sabarti, dkk. 1998. Menulis I. Jakarta: Depdikbud Dirjen Dikdasmen BPPG SLTP Setara D-III.

Alieva, N.F. dkk. 1991. Bahasa Indonesia: Deskripsi dan Teori. Yogyakarta: Kanisius.

Alisjahbana,S. Takdir. 1978. The Concept of Language Standardization and Its Application to the Indonesia Language". Dalam Perez et.al (ed). 19-41.

Alisjahbana,S. Takdir.1983. Tata Bahasa Baru Bahasa Indonesia. Jakarta: Penerbit Dian Rakyat.

Arikunto, Suharsimi. 1997. Prosedur Penelitian Suatu Pendekatan Praktek. Jakarta: Rineka Cipta.

Alwi, Hasan, dkk. 1998. Tata Bahasa Baku Bahasa Indonesia. Jakarta: Balai Pustaka.

Alwi, Hasan. 2003. Tata Bahasa Baku Bahasa Indonesia. Edisi Ketiga. Jakarta: Balai Pustaka.

Alwi, H. \& Sugono, D. 2002. Telaah Bahasa dan Sastra. Jakarta: Yayasan Obor Indonesia.

Anderson, L.W, dan Krathwohl, D.R. 2001. A Taxonomy for Learning, Teaching, and Assesing, A revision of Bloom's Taxonomy of Education Objectives. New York: Addison Wesley Lonman Inc.

Arifin, E. Zaenal dan Tasai. 2010. Bahasa Indonesia sebagai Mata Kuliah Pengembangan Kepribadian. Jakarta: Pustaka Mandiri.

Badudu, J.S. 1999. Memantapkan Peranan Pers dalam Pengembangan Bahasa. Artikel. 
Bloomfield, L. 1995. Language. New York: Holt-Rinehardt and Winston.

Brown, Gillian dan George Yule. 1996. Analisis Wacana. Jakarta: PT Gramedia Pustaka Utama.

Chaer, Abdul. 2012. Linguistik Umum. Jakarta: Rineka Cipta.

Chomsky, Noam. 1965. Aspect of The Theory of Syntax. Cambridge The M.I.T. Press.

Dardjowidjojo, Soenjono. 2008. Psikolinguistik Pengantar Pemahaman Bahasa Manusia. Jakarta: Yayasan Obor Indonesia.

Darmadi, Kaswan. 1996. Meningkatkan Kemampuan Menulis. Yogyakarta: Andi Yogyakarta.

Darsan, Bagus. 2015. Korelasi Penguasaan Kalimat dengan Kemampuan Menulis Argumentasi Mahasiswa PGSD, Fakultas Keguruan dan Ilmu Pendidikan, Universitas Palangka Raya. Jurnal Ilmu Pendidikan, (online), www.jurnalonlinejpips.com Diakses 02 April 2016).

Djaali, Puji Mulyono, dan Ramly. 2000. Pengukuran dalam Bidang Pendidikan. Jakarta: PPs UNJ.

Djiwandono, M.S. 1996. Tes Bahasa dalam Pengajaran. Bandung: ITB.

Dola, Abdullah. 2010. Tataran Sintaksis dalam Gramatika Bahasa Indonesia. Makassar: Badan Penerbit Universitas Negeri Makassar.

Dola, Abdullah. 2011. Linguistik Khusus Bahasa Indonesia. Makassar: Badan Penerbit Universitas Negeri Makassar.

Fokker, A.A. 1972. Sintaksis Indonesia. Jakarta: Pradnya Paramita.

Keraf, Gorys. 1980. Tatabahasa Indonesia. Ende Flores: Nusah Indah.

Keraf, Gorys. 1981. Diksi dan Gaya Bahasa. Ende Flores: Nusah Indah.

Keraf, Gorys. 1987. Argumentasi dan Narasi : Komposisi Lanjutan III. Ende Flores: Nusa Indah.

Keraf, Gorys.1995a. Komposisi. Ende Flores: Nusa Indah.

Keraf, Gorys. 1997. Komposisi. Ende Flores: Nusah Indah.

Keraf, Gorys. 2000. Tata Bahasa Indonesia. Ende Flores: Nusa Indah.

Keraf, Gorys. 2003. Argumentasi dan Narasi. Jakarta: Gramedia.

Kosasih, E. 2003. Kompetensi Ketatabahasaan: Cermat Berbahasa Indonesia Bandung: Yrama Widya.

Kridalaksana, H dan Anton M. Moeliono (ed,).1982. Pelangi Bahasa. Jakarta: Bhratara.

Kridalaksana, H. 1985. Tata Bahasa Deskriptif Bahasa Indonesia: Sintaksis. Jakarta: Pusat Pembinaan dan Pengembangan Bahasa.

Kridalaksana, H. 1993. Kamus Linguistik. Jakarta: PT Gramedia Pustaka Utama.

Lado, Robert. 1964. Language Teaching: A Scientific Approach. Bombay, New Selhi: Tata Mc, Grow Hill Publishing Co.L.td.

Lyons, Jhon. 1963. Structural Semantics an Analysis of Part of Vocabulary of Plato. Cambridge: University Press.

Markhamah. 2013. Ragam dan Analisis Kalimat Bahasa Indonesia. Surakarta: Muhammadiyah University Press.

Moeliono, Anton M. (peny). 1988. Tata Bahasa Baku Bahasa Indonesia. Jakarta: Balai Pustaka. 
Mustakim. 1994. Membina Kemampuan Berbahasa: Panduan ke Arah Kemahiran Berbahasa. Jakarta: Gramedia.

Nafiah, A. Hadi. 1981. Anda Ingin Jadi Pengarang. Surabaya: Usaha Nasional.

Nunan, David. 1991. Language Teaching Metodology A Text For Book For Teacher. New York: Prentice Hall.

Nurgiyantoro, Burhan. 1998. Transformasi Unsur Pewayangan dalam Fiksi Indonesia. 1998. Yogyakarta: Gadjah Mada Universisity Press.

Nurgiyantoro, Burhan. 2001. Penilaian dan Pengajaran Bahasa dan Sastra. Yogyakarta: BPFE Yogyakarta.

Nurgiyantoro. Burhan. 2010. Penilaian Pembelajaran Bahasa Berbasis Kompetensi. Yogyakarta: BPFE.

Patombongi, A.W., dkk. 2008. Telaah Kurikulum. Makassar: Universitas Negeri Makassar.

Putrayasa, I.B. 2012. Jenis Kalimat dalam Bahasa Indonesia. Bandung: Refika Aditama.

Putrayasa, I.B. 2014. Analisis Kalimat (Fungsi, Kategori, dan Peran). Bandung: Refika Aditama.

Ramlan, M. 1987. Ilmu Bahasa Indonesia: Sintaksis.Yogyakarta: CV. Karyono.

Ramlan, M. 1996. Sintaksis. Yogyakarta: CV Karyono.

Samsuri. 1978. Analisis Bahasa. Jakarta: Erlangga.

Samsuri. 1987. Analisis Bahasa. Jakarta: Erlangga.

Sasmayunita. 2015. Hubungan antara Penguasaan Gagasan Utama dan Struktur Kalimat dengan Hasil Belajar Membaca Pemahaman pada Siswa Kelas VIII SMP Negeri 1 Soppeng Riaja Barru. Tesis. Tidak diterbitkan. Makassar: Program Pascasarjana Universitas Negeri Makassar.

Semi, M. Atar. 2003. Menulis Efektif. Padang: Angkasa Raya.

Semi, M. Atar. 2007. Dasar-dasar Keterampilan Menulis. Bandung: Angkasa.

Singgih Santoso, 2001. Mengatasi Berbagai Masalah Statistik dengan SPSS Versi 11,5. Jakarta : Elex Media Kompetindo.

Suparno dan Yunus, M. 2013. Keterampilan Dasar Menulis. Jakarta: Universitas Terbuka.

Suwandi.2006. Perpustakaan Universitas Lampung. (URL: http://digilib.unila.com/go.php?node=20).

Syafi'ie, Iman. 1988. Retorika Dalam Menulis. Jakarta: Depdikbud.

Tarigan, Djago. 1981. Membina Keterampilan Menulis Paragraf dan Pengembangannya. Bandung: Angkasa.

Tarigan, Henry Guntur. 1986. Menulis: Pengajaran Pragmatik. Bandung: Angkasa.

Tarigan, Henry Guntur. 1992. Menulis: Sebagai Suatu Keterampilan Berbahasa. Bandung: Angkasa.

Tarigan, Djago.1996. Membina Keterampilan: Menulis Paragraf dan Pengembangan. Bandung: Angkasa.

Tarigan, Henry Guntur. 2008. Menulis: Sebagai Suatu Keterampilan Berbahasa. Bandung: Angkasa. 
Volume 5 Nomor 2

Verhaar, J.W.M. 1977. Pengantar Lingguistik. Yogyakarta: Gadjah Mada University Press.

Verhaar, J.W.M. 1996. Asas-Asas Linguistik Umum. Yogyakarta: Gadjah Mada University Press.

Widdowson, H.G. 1978. Teaching Language as Communication. Oxford: Oxford University.

Wiyanto, Asul. 2004. Terampil Menulis Paragraf. Jakarta: Grasindo.

Zuchdi, Darmiyati. (1995). "Pembelajaran Menulis dengan Pendekatan Proses", Karya Ilmiah disajikan dan dibahas pada Senat Fakultas Pendidikan Bahasa dan Seni IKIP Yogyakarta tanggal 15 November 1996. Yogyakarta: IKIP. Yogyakarta. 